\title{
Thermodynamic analysis of a combined gas-steam cycle without and with afterburner
}

\section{Análisis termodinámico de un ciclo combinado gas-vapor sin y con Postcombustión}

\author{
CASADOS-LÓPEZ, Edzel Jair†**, CASADOS-SÁNCHEZ, Alvaro, ESCAMILLA-RODRÍGUEZ, \\ Frumencio and CORTÉZ-DOMÍNGUEZ, Cristóbal
}

Universidad Veracruzana, Facultad de Ingeniería Mecánica Eléctrica, Campus Poza Rica - Tuxpan, Veracruz, México.

ID $1^{\text {st }}$ Author: Edzel Jair, Casados-López / ORC ID: 0000-0002-0601-9242

ID $1^{\text {st }}$ Coauthor: Alvaro, Casados-Sánchez / ORC ID: 0000-0002-3122-4571

ID $2^{\text {nd }}$ Coauthor: Frumencio, Escamilla-Rodríguez / ORC ID: 0000-0002-5075-1924 / CVU CONACYT ID: 1134105

ID $3^{\text {rd }}$ Coauthor: Cristóbal, Cortez-Domínguez / ORC ID: 0000-0002-5720-4405 / CVU CONACYT ID: 972957

DOI: $10.35429 / J O E S .2021 .24 .8 .17 .24$

Received 09 March, 2021; Accepted 28 June, 2021

\begin{abstract}
Currently in power plants what is sought are higher thermal efficiencies, which is why combined cycle plants have been chosen, since they make better use of fuel, producing greater net power, all this It has led to innovative modifications to combined cycle power plants, improving their performance. In this article the thermodynamic analysis of a combined cycle (Gas-Steam) without and with Afterburner is carried out, in said analysis adequate thermodynamic indices have been used and the calculations have been carried out taking into account the state of the art for gas turbines and the typical values for steam cycle quantities. The purpose of this study is to analyze the combined plants where the exhaust gas at the outlet of the gas turbine is used in a waste heat recovery boiler to produce steam that is expanded in a turbine and discharged in a condenser. Since the air-fuel ratio in the combustion chamber of a gas turbine is higher than the stoichiometric, fuel can be added in the boiler (Afterburner) to increase steam production or to improve the quality of the steam produced.
\end{abstract}

Combined cycle plant (Gas-Steam), Afterburner, Recovery boiler

\section{Resumen}

En la actualidad en las plantas de energía lo que se busca son eficiencias térmicas más altas, es por lo que se ha optado por las centrales de ciclo combinado, ya que en ellas se aprovecha mejor el combustible, produciendo una mayor potencia neta, todo esto ha originado modificaciones innovadoras en las centrales de ciclo combinado, mejorando el rendimiento de este. En este artículo se lleva a cabo el análisis termodinámico de un ciclo combinado (Gas-Vapor) sin y con Postcombustión, en dicho análisis han sido utilizados índices termodinámicos adecuados y los cálculos se han realizado teniendo en cuenta el estado del arte para turbinas de gas y los valores habituales para las cantidades de los ciclos de vapor. El propósito de este estudio es analizar las plantas combinadas donde el gas de escape a la salida de la turbina de gas es utilizado en una caldera de recuperación de calor residual para producir vapor que es expandido en una turbina y descargado en un condensador. Ya que la relación aire-combustible en la cámara de combustión de una turbina de gas es mayor al estequiométrico, se puede añadir combustible en la caldera (Postcombustión) para aumentar la producción de vapor o para mejorar la calidad del vapor producido.

Ciclo combinado (Gas-Vapor), Postcombustión, Caldera de recuperación

Citation: CASADOS-LÓPEZ, Edzel Jair, CASADOS-SÁNCHEZ, Alvaro, ESCAMILLA-RODRÍGUEZ, Frumencio and CORTÉZ-DOMÍNGUEZ, Cristóbal. Thermodynamic analysis of a combined gas-steam cycle without and with afterburner. Journal of Experimental Systems. 2021. 8-24: 17-24

\footnotetext{
* Correspondence to Author (Email: torlia@ hotmail.com).

$\dagger$ Researcher contributing as first Author.
} 


\section{Introduction}

Man has a natural tendency to try to improve the efficiency of devices in converting thermal energy into mechanical work. Moreover, the rising costs of fossil fuels as well as the care of the environment is a stimulus for this type of research. Power plants where gas turbines, operating in open cycle, are combined with steam cycles, are of particular interest because of their high conversion efficiency. The combination of these two types of cycles is possible due to the high temperature heat in the turbine exhaust, which depends on the ratio of gas temperature and maximum pressure. For many years the focus of manufacturers and utilities has been on combined cycles (GasSteam). Many combinations are possible and gas turbines, in addition to generating mechanical power, can perform different tasks according to their position in the plants.

Pfenninger analysed a plant in which the maximum gas temperature was $\mathrm{T} 3 \mathrm{a}=880{ }^{\circ} \mathrm{C}$ and concluded that the gas turbine cycle must have the maximum exhaust enthalpy (i.e. the maximum product between the mass flow of the gas and its temperature). The resulting pressure ratio was intermediate between these for which the gas turbine specific work and efficiency are maximum. The afterburner was taken into consideration and the conclusions were that for a low afterburner rate the efficiency decreases slightly, then a maximum is reached in the ratio between gas turbine power and total plant power. An excess of air comprises this ratio.

The total output went up with minimal excess air in the exhaust gas. Wunsch, stated that the efficiency of a combined gas-steam plant is mostly influenced by the gas turbine parameters (T3a , $\beta$ ) what by the steam cycles, the parameters were set in an appropriate way. The conclusion was that the maximum efficiency of the combined Gas-Steam cycle was reached when the exhaust temperature of the gas turbine was higher than the corresponding maximum efficiency of the gas turbine. In the same study the afterburner was taken into consideration and its influence was positive when the maximum gas turbine temperature was lower than $950^{\circ} \mathrm{C}$ and negative for higher temperatures.
In the present study, a thermodynamic analysis of a combined Gas-Steam cycle is carried out, with one pressure level, with no regeneration drawdowns. The results of the parametric analysis of the cycle performance are given.

\section{Nomenclature}

$\mathrm{T}=$ Temperature

$\mathrm{P}=$ Pressure

$\mathrm{V}=$ Volume

$\mathrm{Cp}=$ Specific heat at constant pressure

$\mathrm{kP}=$ Pressure loss coefficient

$\mathrm{h}=$ Enthalpy

$\mathrm{pc}=$ Pressure in the condenser in Mpa.

$q=$ Ratio of heat in the afterburner to heat in the combustion chamber and the heat in the combustion chamber of the combustion chamber of the gas turbine

$\mathrm{s}=$ Entropy

$\mathrm{S}=$ Mass ratio air - vapour

T6a, t6a $=$ Temperature at discharge, ${ }^{\circ} \mathrm{C}, \mathrm{K}$

$\mathrm{Tc}, \mathrm{tc}=$ Condenser temperature, ${ }^{\circ} \mathrm{C}, \mathrm{K}$

$\mathrm{x}=$ Steam quality at the outlet of the steam turbine steam turbine outlet steam quality

$\dot{\mathrm{W}}=$ Work, $\mathrm{KJ}$

$\mathrm{Q}=$ Heat, $\mathrm{KJ}$

Wo $=$ Specific work, $\mathrm{KJ} / \mathrm{Kg}$

$\alpha=$ Air-fuel mass ratio

$\alpha s t=$ Stoichiometric air-fuel mass ratio

$\beta \mathrm{gt}=$ Pressure ratio of gas turbine

$\beta \mathrm{st}=$ Steam turbine pressure ratio

$\Gamma i=$ Net heat output $\mathrm{KJ} / \mathrm{Kg}$

$\mathrm{Cb}=$ Steam generator efficiency

$\Upsilon=$ Fraction of compressed air for cooling of blades and accessories.

$\mathrm{Vs}=\mathrm{R} / \mathrm{Cp}=$ Ratio of gas constant to specific heat constant at constant pressure in the transformation.

$\mathrm{Wn}=$ Net work

Wgt $=$ Work of the gas turbine

Wst $=$ Work of steam turbine

$\mathrm{CC}=$ Combined Cycle

$\mathrm{WCC}=$ Net combined cycle work

QS = Heat supplied

Q.gt $=$ Thermal efficiency of the gas turbine

$\Omega_{\text {st }}=$ Thermal efficiency of steam turbine steam turbine thermal efficiency

ح.CC $=$ Thermal efficiency of combined cycle

The schematic diagram of the simple gassteam combined cycle is presented below. 


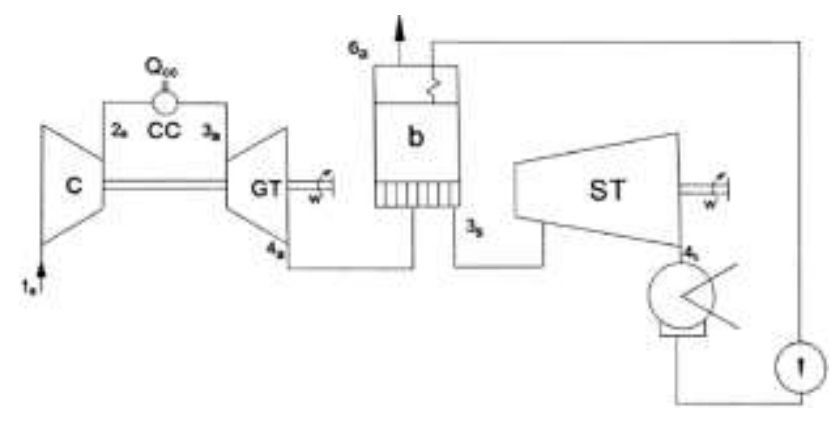

Figure 1 Schematic diagram of the simple combined gassteam cycle

Source: Own Elaboration

In the following, the thermodynamic calculations of the simple combined cycle are presented, whose reference was taken from the: Cerri, G., (1987) Parametric analysis of combined gas - steam cycles. Journal of Engineering for Gas Turbines and Power, vol. 109, pag. 46 - 54.

\section{Compression}

$\mathrm{T}_{2 \mathrm{a}}=\left(\mathrm{T}_{1}\right)\left(\beta^{\mathrm{va} 12 / \eta \mathrm{pc}}\right)$

$\mathrm{T}_{2 \mathrm{a}}=(305 \mathrm{~K})\left(14^{0.285 / 0.85}\right)$

\section{$T_{2 a}=738.91 \mathrm{~K}$}

Taking into account the friction of the compressed air to cool the blades and accessories.

$$
Y=0.05 \quad \text { sí } \quad \mathrm{T}_{3 \mathrm{a}} \leq 1273 \mathrm{~K}
$$

sí:

$\mathrm{T}_{3 \mathrm{a}} \geq 1273 \mathrm{~K}$

$Y=\frac{0.05\left(T_{3 a}-273\right)}{1000}$

$\boldsymbol{Y}=\frac{0.05(1536-273)}{1000}$

$$
Y=0.06315
$$

The work absorbed by the compressor is:

$\mathrm{Wc}=\frac{C_{\mathrm{pa} 1-2}}{\eta \mathrm{mc}}\left(\mathrm{T}_{2 a}-T_{1}\right)(1+\gamma)$

$\mathrm{Wc}=\frac{1.005}{0.98}(738.91-305)(1+0.06315)$

$\mathrm{Wc}=473.08 \mathrm{KJ} / \mathrm{Kg}$

\section{Gas Turbine Combustion}

The energy balance of the combustion chamber is:

$$
\frac{\Gamma i \eta b_{\mathrm{gt}}}{\alpha_{\mathrm{gt}}}=\left(1+\frac{1}{\alpha_{\mathrm{gt}}}\right) C_{\mathrm{pa} 2-3}\left(T_{3 a}-T_{2 a}\right)
$$

The air-fuel ratio is:

$$
\begin{aligned}
& \alpha_{\mathrm{gt}}=\frac{\Gamma I \eta \mathrm{b}_{\mathrm{gt}}}{C_{\mathrm{pa} 2-3}\left(T_{3 a}-T_{2 a}\right)}-1 \\
& \alpha_{\mathrm{gt}}=\frac{48490(0.98)}{1.0838(1536-738.91)}-1 \\
& \alpha_{\mathrm{gt}}=54.0
\end{aligned}
$$

Heat Supplied

$Q s=\frac{\Gamma I \eta \operatorname{bgt}}{\alpha_{\mathrm{gt}}}$

$Q s=\frac{(48490)(0.98}{54.0}$

$\mathrm{Qs}=880 \mathrm{KJ} / \mathrm{Kg}$

\section{Expansion in the gas turbine}

$\beta_{\mathrm{gt}}=\mathrm{k}_{\mathrm{p}} \beta_{c}$

$\beta_{\mathrm{gt}}=(0.9238)(14)=12.9332$

$K_{p}=\frac{\left(1-\frac{\Delta \mathrm{p}_{2 a}}{\mathrm{P}_{2 a}}\right)}{\left(1+\frac{\Delta \mathrm{p}_{4} a}{P_{4 a}}\right)}$

$K_{p}=\frac{0.97}{1.05}=0.9238$

$T_{4 a}=\frac{T_{3}}{\beta_{\mathrm{gt}}^{\mathrm{va} 34 \eta p g t}}$

$T_{4 a}=\frac{1536}{12.9332^{((0.2366)(0.8837))}}=\frac{1536}{1.7074}$

$T_{4 a}=899 \mathrm{~K}$

$\mathrm{Wgt}=\left(1+\frac{1}{\alpha \mathrm{gt}}\right) C_{\mathrm{pa} 3-4}\left(T_{3}-T_{4 a}\right) \eta_{m g t}$

Wgt $=\left(1+\frac{1}{54}\right) 1.2136(1536-899) 0.98$

$\mathrm{Wgt}=770.88 \mathrm{KJ} / \mathrm{Kg}$ 
$\eta_{\mathrm{gt}}=\frac{770.88-473.08}{800}=0.3384=33.84 \%$

The enthalpy of steam at the boiler outlet is:

$H_{3 s}=H\left(T_{3 s}, p_{2 s}\right)$

$T_{3 \mathrm{~s}}=523^{\circ} \mathrm{C}=796 \mathrm{~K}$

$P_{2 \mathrm{~s}}=7.742 \mathrm{Mpa}$

$\mathrm{H}_{3 \mathrm{~s}}=3457.87 \mathrm{KJ} / \mathrm{Kg}$

The enthalpy of the condenser feed water is:

$h_{\mathrm{c}}=h\left(p_{\mathrm{c}}\right)$

$p_{\mathrm{c}}=8.91 \mathrm{kpa}$

$\mathrm{h}_{\mathrm{c}}=182.46 \mathrm{KJ} / \mathrm{Kg}$

The energy balance in the generator can be expressed as:

$\left(1+\frac{1}{\alpha}\right) C_{\mathrm{pa} 4-6}\left(T_{4 a}-T_{6 a}\right) \epsilon_{\mathrm{b}}=S\left(H_{3 s}-h_{c}\right)$

$C_{\text {pa4-6 }}=1.12 \mathrm{KJ} \mathrm{Kg} / \mathrm{K}$

$T_{4 \mathrm{a}}=899.61 \mathrm{~K}$

$T_{6 \mathrm{a}}=363.6 \mathrm{~K}$

$\epsilon_{\mathrm{b}}=0.96$

By subtracting the vapour-air mass ratio (S)

$S=\frac{\left(1+\frac{1}{\alpha}\right) C_{\mathrm{pa} 4-6}\left(T_{4 a}-T_{6 a}\right) \epsilon_{\mathrm{b}}}{\left(H_{3 S}-h_{c}\right)}$

$S=0.1878$

\section{The work of steam expansion}

The adiabatic efficiency of the steam turbine expansion can be expressed by $P_{-} 2$ s and $P_{-} c$ and the polytropic efficiency. As:

$$
\begin{aligned}
& \beta_{\mathrm{st}}=\frac{P_{2 \mathrm{~s}}}{P_{\mathrm{c}}} \\
& \beta_{\mathrm{st}}=\frac{7742 \mathrm{kpa}}{8.91 \mathrm{kpa}} \\
& \beta_{\mathrm{st}}=868.91
\end{aligned}
$$

$\eta_{\mathrm{ast}}=\frac{\beta_{\mathrm{st}}^{\mathrm{Vs} \eta p s t}-1}{\beta_{\mathrm{st}}^{\mathrm{Vs}}-1} \beta_{\mathrm{st}}^{\mathrm{Vs}\left(1-\eta_{\mathrm{pst}}\right)}$

$\eta_{\text {ast }}=0.9365$

The entropy of the steam at the turbine inlet is:

$s_{3 s}=s\left(T_{3 s}, p_{2 s}\right)$

$s_{3 \mathrm{~s}}=6.8149 \mathrm{KJ} \mathrm{Kg} / \mathrm{K}$

Quality at the turbine outlet:

$x=\frac{6.8149-0.61515}{7.5821}=0.8176$

$\mathrm{H}_{\mathrm{cs}}=\mathrm{H}\left(S_{3 s}, p_{c}\right)$

$\mathrm{H}_{\mathrm{cs}}=H_{\mathrm{f}}+x H_{\mathrm{fg}}$

$\mathrm{H}_{\mathrm{cs}}=2143.88 \mathrm{KJ} / \mathrm{Kg}$

$\eta_{\mathrm{tv}}=\frac{H_{3 s}-h_{4 s}}{H_{3 s}-H_{C S}}$

$\mathrm{h}_{4 \mathrm{~s}}=2227.32 \mathrm{KJ} / \mathrm{Kg}$

Steam turbine work:

$W_{\text {st }}=s\left(H_{3 s}-h_{4 s}\right) \eta_{\text {ast }} \eta_{\mathrm{mst}}$

$\mathrm{W}_{\mathrm{st}}=212.09 \mathrm{KJ} / \mathrm{Kg}$

Heat supplied:

$Q_{\mathrm{s}}=s\left(H_{3 s}-h_{c}\right)$

$Q_{\mathrm{s}}=615.12 \mathrm{KJ} / \mathrm{Kg}$

Thermal efficiency of the steam turbine:

$\eta_{\mathrm{st}}=\frac{\mathrm{w}_{\mathrm{st}}}{Q_{\mathrm{s}}}$

$\eta_{\text {st }}=0.3448=34.48 \%$

The schematic diagram of the combined gas-steam cycle with afterburner is shown below. 


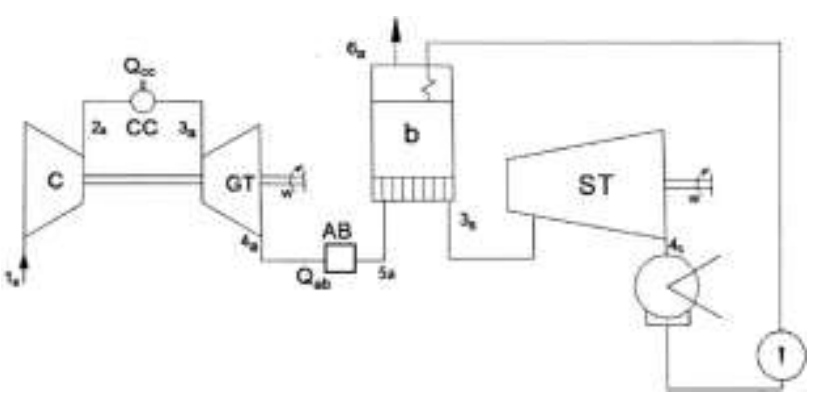

Figure 2 Schematic diagram of the combined gas-steam cycle with afterburner Source: Cerri

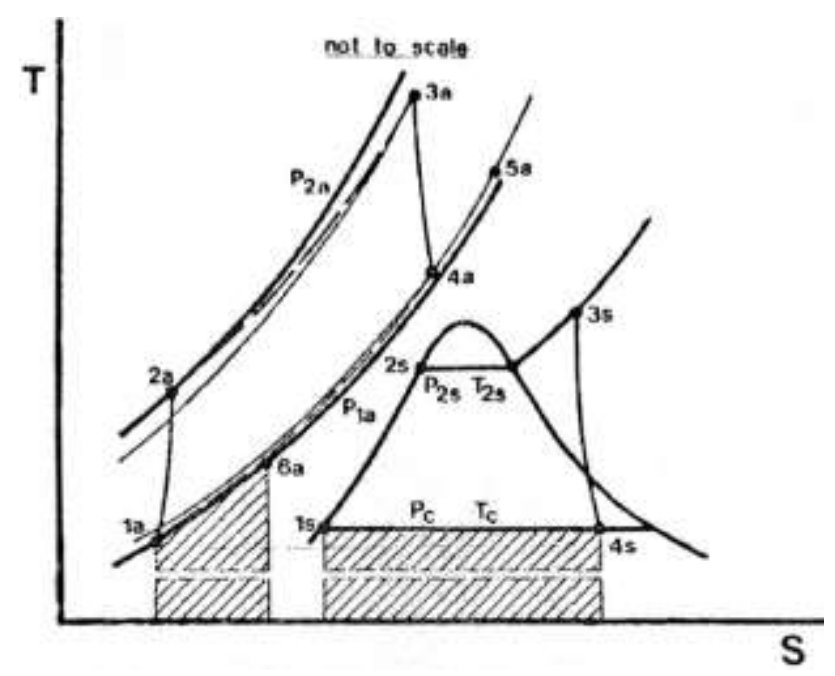

Figure 3 T-S diagram of the combined gas-steam cycle with afterburner

Source: Cerri

The T-S diagram of the combined gas vapour cycle with afterburner, starts with the compressor drive by admitting air at atmospheric conditions (1a), increases the pressure and temperature up to (2a), this air is supplied to the combustion chamber, in which the fuel is also injected. Combustion takes place, resulting in high-temperature combustion gases (3a). After combustion, the gases go to the turbine where the transformation of thermal energy to mechanical energy takes place, leaving in conditions (4a), it continues to the afterburner chamber where the thermal energy is increased leaving in (5a), it continues to the heat recuperator where the gases transfer heat to the water, being discharged to the atmosphere (6a).

The liquid that is supplied to the heat recovery unit comes out as superheated steam to enter the steam turbine (3s), after the transformation it comes out as a steam with quality ( $4 \mathrm{~s})$, in the condenser the condensation of this steam is carried out (1s), finally this liquid is propelled towards the heat recovery unit to start the cycle again.
The thermodynamic calculations for this cycle are presented below:

The work and thermal efficiency of the gas turbine is the same as for the combined cycle without post-combustion, therefore, the calculations will no longer be carried out.

\section{Heat recovery steam generator}

We define $\alpha \_a b$ as the ratio of compressed air to fuel used in the afterburner, the final air - fuel mass ratio is:

$\alpha=\frac{\alpha_{\mathrm{gt}} \alpha_{\mathrm{ab}}}{\alpha_{\mathrm{gt}}+\alpha_{\mathrm{ab}}}$

Which, expressed in stoichiometric ratio and with excess air, is:

$$
\begin{aligned}
& \alpha=\alpha_{\mathrm{gt}}(1+e) \\
& \alpha=14(1+0.06)=14.84
\end{aligned}
$$

Therefore, the ratio of the afterburner fuel to the fuel in the combustor of the gas turbine is:

$$
\begin{aligned}
& \mathrm{q}=\frac{\alpha_{\mathrm{gt}}}{\alpha_{\mathrm{st}}(1+e)}-1 \\
& \mathrm{q}=\frac{54}{14.84}-1 \\
& \mathrm{q}=2.6388 \\
& \mathrm{q}=\frac{\alpha_{\mathrm{gt}}}{\alpha_{\mathrm{ab}}} \\
& \alpha_{\mathrm{ab}}=\frac{\alpha_{\mathrm{gt}}}{\mathrm{q}} \\
& \alpha_{\mathrm{ab}}=20.46
\end{aligned}
$$

The heat balance in the afterburner can be expressed as:

$$
\begin{aligned}
& \left(1+\frac{1}{\alpha}\right) C_{\mathrm{pa} 5} T_{5 a}=\left(1+\frac{1}{\alpha_{\mathrm{gt}}}\right) C_{\mathrm{pa} 4} T_{4 a}+\frac{\Gamma \text { Inbgt }}{\alpha_{\mathrm{gt}}} \\
& T_{5 a}=\frac{\left(1+\frac{1}{\alpha_{\mathrm{gt}}}\right) C_{\mathrm{pa} 4} T_{4 a}+\frac{\Gamma I \eta \mathrm{bgt}}{\alpha_{\mathrm{gt}}}}{\left(1+\frac{1}{\alpha}\right) C_{\mathrm{pa} 5}} \\
& T_{5 a}=\frac{\left(1+\frac{1}{54}\right)(1.1204)(899.61)+\frac{48490(0.98)}{74.46}}{\left(1+\frac{1}{14.84}\right)(1.1204)}
\end{aligned}
$$


The enthalpy of the steam at the boiler outlet is:

$$
\begin{aligned}
& \mathrm{H}_{3 \mathrm{~s}}=\mathrm{H}\left(T_{3 s}, p_{2 s}\right) \\
& T_{3 \mathrm{~s}}=523^{\circ} \mathrm{C} \\
& p_{2 \mathrm{~s}}=7.742 \mathrm{Mpa} \\
& \mathrm{H}_{3 \mathrm{~s}}=3457.87 \mathrm{KJ} / \mathrm{Kg}
\end{aligned}
$$

The enthalpy of the feed water in the condenser is:

$\mathrm{H}_{\mathrm{c}}=\mathrm{h}\left(p_{c}\right)$

$\mathrm{p}_{\mathrm{c}}=0.00891 \mathrm{Mpa}$

$\mathrm{H}_{c}=182.46 \mathrm{KJ} / \mathrm{Kg}$

The energy balance in the steam generator can be expressed as:

$$
\begin{aligned}
& \left(1+\frac{1}{\alpha}\right) C_{\mathrm{pa} 5-6}\left(T_{5 a}-T_{6 a}\right) \epsilon_{\mathrm{b}}=S\left(h_{3 s}-h_{c}\right) \\
& \left(1+\frac{1}{14.84}\right)(1.198)(1392.06- \\
& 363.60)(0.96)=S(3457.87-182.46) \\
& S=\frac{1262.41}{3275.41} \\
& S=0.3854
\end{aligned}
$$

With the

$$
p=7.742 \quad \text { You get } \quad \mathrm{H}_{2 \mathrm{~s}}=1304.53
$$

\section{Steam expansion work}

The adiabatic efficiency of the steam turbine expansion can be expressed by $\mathrm{p} \_2 \mathrm{~s}, \mathrm{p} \_\mathrm{c}$ and the polytropic efficiency. As $\beta \_s t=p_{2} 2 s / p_{-} c$ the adiabatic efficiency is:

$$
\begin{aligned}
& \eta_{\mathrm{ast}}=\frac{\beta_{\mathrm{st}}^{\mathrm{Vs} \eta_{\mathrm{pst}}}-1}{\beta_{\mathrm{st}}^{\mathrm{Vs}}-1} \beta_{\mathrm{st}}^{\mathrm{Vs}\left(1-\eta_{\mathrm{pst}}\right)} \\
& \beta_{\mathrm{st}}=\frac{P_{2 \mathrm{~s}}}{P_{\mathrm{c}}}=\frac{7742}{8.91}=868.91 \\
& \mathrm{~V}_{\mathrm{s}}=\frac{R}{C_{\mathrm{p}}}=\frac{0.4615}{2.1465}=0.2150 \\
& \eta_{\mathrm{ast}}=\left[\frac{868.91^{0.2150(0.86)}-1}{868.91^{0.2150}-1}\right] 868.91^{0.2150(1-0.86)} \\
& \eta_{\mathrm{ast}}=0.9312
\end{aligned}
$$

The entropy of the steam at the turbine inlet is:

$$
\begin{gathered}
\mathrm{T}=523^{\circ} \mathrm{C} \\
\mathrm{P}=7.742 \mathrm{Kpa}
\end{gathered} \quad\left\{\mathrm{S}_{3 \mathrm{~s}}=6.8149 \mathrm{KJ} / \mathrm{Kg} \mathrm{K}\right.
$$

The final state of the isentropic expansion is:

$$
\begin{aligned}
& \mathrm{H}_{\mathrm{cs}}=\mathrm{H}\left(S_{3 s}, p_{c}\right) \\
& x=\frac{6.8149-0.61515}{7.5821}=0.8176 \\
& \mathrm{H}_{\mathrm{cs}}=\mathrm{H}_{\mathrm{f}}+x \mathrm{H}_{\mathrm{fg}} \\
& \mathrm{H}_{\mathrm{cs}}=2143.88 \mathrm{KJ} / \mathrm{Kg} \\
& \mathrm{h}_{4 \mathrm{a}}=3457.87-(3457.87-2143.88) 0.93 \\
& \mathrm{~h}_{4 \mathrm{a}}=2227.32 \mathrm{KJ} / \mathrm{Kg}
\end{aligned}
$$

\section{Steam turbine work}

$\mathrm{w}_{\mathrm{st}}=S\left(H_{3 s}-h_{4 s}\right) \eta_{\mathrm{ast}} \eta_{\mathrm{mst}}$

$\mathrm{W}_{\mathrm{st}}=0.3854(3457.87-$

$2227.32)(0.9312)(0.98)$

$\mathrm{W}_{\text {st }}=432.79 \mathrm{KJ} / \mathrm{Kg}$

\section{Heat supplied}

$\mathrm{Q}_{\mathrm{S}}=S\left(H_{3 s}-h_{c}\right)$

$\mathrm{Q}_{\mathrm{S}}=0.3854(3257.87-182.46)$

$\mathrm{Q}_{\mathrm{S}}=1262.34 \mathrm{KJ} / \mathrm{Kg}$

\section{Steam and gas turbine thermal efficiency:}

$$
\begin{aligned}
& \eta_{\mathrm{gt}}=\frac{\mathrm{w}_{\mathrm{tg}}-\mathrm{w}_{\mathrm{c}}}{Q_{\mathrm{s}}} \\
& \eta_{\mathrm{gt}}=\frac{297.80}{880} \\
& \eta_{\mathrm{gt}}=0.3384=33.84 \% \\
& \eta_{\mathrm{st}}=\frac{\mathrm{w}_{\mathrm{st}}}{Q_{\mathrm{s}}} \\
& \eta_{\mathrm{st}}=\frac{432.79}{1262.34} \\
& \eta_{\mathrm{st}}=0.3428=34.28 \%
\end{aligned}
$$


Thermal efficiency of the combined cycle:

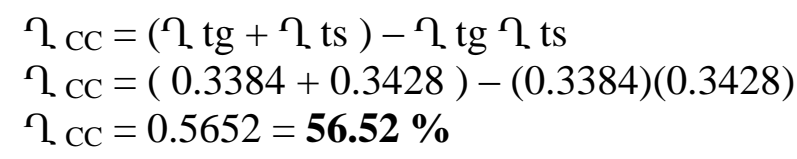

The following table compares the combined gas-steam cycles without and with afterburners.

\begin{tabular}{|c|c|c|c|c|c|}
\hline $\begin{array}{l}\text { Combined } \\
\text { Cycle }\end{array}$ & Wc & Wgt & Wst & $\mathbf{W}_{\mathbf{C C}}$ & $\begin{array}{l}\mathbf{2} \\
\mathrm{CC}\end{array}$ \\
\hline $\begin{array}{l}\text { Without Post } \\
\text { Combustion }\end{array}$ & 473.08 & 770.88 & 212.09 & 509.89 & 54.6 \\
\hline $\begin{array}{l}\begin{array}{l}\text { With } \\
\text { afterburner }\end{array} \\
\end{array}$ & 473.08 & 770.88 & 435.25 & 773.05 & 54.6 \\
\hline
\end{tabular}

Table 1 Comparative table of work in $(\mathrm{KJ} / \mathrm{Kg})$ and thermal efficiency in (\%) for the combined cycles with and without afterburner

Source: Own Elaboration

\section{Conclusions and Results}

Combined gas-steam cycles for power generation are of great interest, due to the high efficiency that can be obtained. In this research work, a comparison of a combined gas-steam cycle without and with post-combustion was carried out, where the advantage of adding a complementary combustion system before the heat recovery system was determined, obtaining the following results: combustion:

For the case of the cycle without post-

$$
\begin{aligned}
& \mathrm{Wc}=473.08 \mathrm{KJ} / \mathrm{Kg} \\
& \mathrm{Wgt}=770.88 \mathrm{KJ} / \mathrm{Kg} \\
& \mathrm{Wst}=212.09 \mathrm{KJ} / \mathrm{Kg} \\
& \mathrm{W}_{\mathrm{CC}}=509.89 \mathrm{KJ} / \mathrm{Kg} \\
& \mathrm{\chi}_{\mathrm{CC}}=0.5465=54.65 \%
\end{aligned}
$$

For the case of the afterburner cycle:

$$
\begin{aligned}
& \mathrm{Wc}=473.08 \mathrm{KJ} / \mathrm{Kg} \\
& \mathrm{Wgt}=770.88 \mathrm{KJ} / \mathrm{Kg} \\
& \mathrm{Wst}=435.25 \mathrm{KJ} / \mathrm{Kg} \\
& \mathrm{W}_{\mathrm{CC}}=773.05 \mathrm{KJ} / \mathrm{Kg} \\
& \mathrm{\Upsilon}_{\mathrm{CC}}=0.5465=54.65 \%
\end{aligned}
$$

These results indicate that when using post-combustion in a combined gas-steam cycle as in this case study, the only variation that exists is in the steam turbine due to the difference in the steam-air mass ratios.

\section{References}

Aschener, F. S. (1972). The Optimal Choice of Heat Engines for Power Plants of $10 \mathrm{MW}$ to 250 MW Electric Output. Israel Journal of Technology, Vol. 10, No. 4, pp. 223 - 231.

Carmona Contrera, S.A. (2008). Estudio de controladores de ciclo combinado para el mejoramiento de la respuesta dinámica de la unidad. Pontifica Universidad Católica de Chile. Santiago de Chile. Tesis Maestría.

Cerri, G., (1987). "Parametric Analysis of Combined Gas Steam Cycles", Journal of Engineering for Gas Turbines and Power, vol 109. 46-54.

Cerri, G., (2015). "Parametric Analysis of Combined Gas Steam Cycles", ASME Paper No. 82-GT-95.

Fraize, W. E., and Kinney, C., (1979). Effects of Steam Injection on the Performance of Gas Turbine Power Cycles. "ASME Journal of Engineering for Power, Vol. 101, pp. 217-227.

Hernández-Fernández, N. J., Zumalacárregui-de Cárdenas, L., \& Perez-Ones, O. (2020). Simulación de condiciones de operación y fluidos de trabajo para ciclos Rankine orgánicos. Revista de investigación, Desarrollo e Innovación, 10(2).

Jassim, R. K., Zaki, G.M., Alhazmy, M.M., (2010). Thermo - Economic analysis of a gas turbine power plant with cooled air intake, Yanbu Journal of Engineering ans Sciencie.

Kakaras, E, Doukelis, A., Prelipceanu, A., Karellas, S., (2006). Inlet air cooling Methods for gas turbine based power plants, Journal of Engineering for GasTurbines and Power, Vol. 128,312-317.

Kehlhofer R (1997). Combined cycle Gas and steam Turbine power Plant pennwell publishing company ISBN-0-87814-736-5. 
L. J. Nayak, D. Mahto. (2014). Parametric Analysis of Combined Cycle Power Plant Using Inlet Vapour Compression Cycle. International Journal of Emerging Technology and Advanced Engineering.

Mendoza Nalvarte, J. (2002). Análisis del diseño termodinámico de centrales eléctricas de ciclo combinado. Repositorio Institucional de la Universidad de Piura. Tesis de Licenciatura.

Nag P.K. (2009). Power Plant Engineering. Tata McGraw-Hill Publishingcompany limited. New Delhi ISBN13: 978-0-07-064815- 9 .

Olguin Mejia, A. (2010). Optimización de la planta de ciclo combinado Tula: Sustitución de las calderas de recuperación de calor. Repositorio Institucional UNAM. México. Tesis de Maestría.

Ondryas, I.S., Wilson, D. A., Kawamoto, M., Haub G.L., (1991). Option in gas Turbine power augmentation using inlet air chilling, engineering gas turbine and power, ASME 113 203-2012

Pfenninger, H., (1982). "Combined steam and gas turbine power stations, Brown Boveri, Paper No. CH-T 040013E

Quiñones Gutierrez, E. M., \& Saldaña Castillo, E. A. (2020). Diseño de una central termoeléctrica de cogeneración de $5 \mathrm{MW}$ para la planta Backus-Motupe.

Sanjay (2013), Energy and exergy analysis of combined cycle systems with different bottoming cycle configurations, Int J.Energy Res. 37: 899-912.

Sanjay, Onkar Singh, B N Prasad, (2008). Infuence of different means of Turbine blade cooling on thermodynamic performance of combined cycle, Applied thermal Engineering 28 2315-2326.

Santos, A.P., (2012). Analysis of gas Turbine Performance with inlet air Cooling techniques, appliedtoBraziliansites, J. Aerospace. Technol Manag. Vol. 4. No. 3, pp.314-353.
Sonneuschain, H., (1982). A Modular Optimizing Calculation Method of Power Station Energy Balance and Plant Efficiency. "ASME Journal of Engineering of Power, Vol. 104, pp. $225-259$

Subugal Garcia, S., \& Gomez Moñux, F. (2006). Centrales Térmicas de Ciclo combinado: Teoría y Proyecto. Fernández: Díaz de Santos.

Tomlinson, L. O. and George, R. L., (1981). Scelta di una turbina a gas e di un ciclo a vapore per il Massimo rendimiento di un ciclo combinato. Nuovo pignone, Energía totale dalle Turbine a Gas, Firenze. pp. 1-9.

Wunsch A. (1978). Centrales combinees a turbines a gaz et a vapeur. Situation actualle et développements futurs, "Rev. Brown Boveri, Vol. 65, No. 10, Oct, pp. 646-655.

Yadav R (2004) steam and gas turbine and Power plant Engineering. Central publishing House, Allahabad. 